\title{
Modified Diode Assisted Extended Boost Quasi Z-Source Inverter for PV Applications
}

\author{
N. Hemalatha ${ }^{*}$, R. Seyezhai ${ }^{2}$ \\ ${ }^{1}$ Department of EEE, Meenakshi College of Engineering, Chennai, India \\ ${ }^{2}$ Department of EEE, SSN College of Engineering, Chennai, India \\ Email: "rnhemaa@gmail.com
}

Received 7 April 2016; accepted 1 May 2016; published 25 August 2016

Copyright (C) 2016 by authors and Scientific Research Publishing Inc.

This work is licensed under the Creative Commons Attribution International License (CC BY). http://creativecommons.org/licenses/by/4.0/

(c) (i) Open Access

\section{Abstract}

The design, simulation and implementation of modified diode assisted extended boost q-ZSI (MDAEB q-ZSI) for photovoltaic application are proposed in this paper. It is the most efficient topology that provides a single stage conversion for $\mathrm{PV}$ systems by providing high input voltage gain, reduced number of components count, increased voltage boost property, reduced voltage ratings, reduced voltage stress across the switches and simplified control strategies. Its unique capability in single stage conversion with improved voltage gain is used for voltage buck and boost function. The operating modes and the steady state theoretical analysis of voltage boost, control methods and a system design guide for the proposed topology are investigated in this paper. A simulation model of the PV system based on MDAEB q-ZSI has been built in MATLAB/ SIMULINK. Performance parameters such as Total harmonic distortion (THD), voltage gain, voltage stress and boost factor are computed and compared with the conventional quasi z-source inverter. The prototype model for MDAEB q-ZSI is developed and the results are validated.

\section{Keywords}

Modified Diode Assisted Extended Boost (MDAEB), Shoot-Through, THD, Boost Factor, Voltage Gain, Voltage Stress

\section{Introduction}

In standalone PV systems, the power electronic converters play a vital role in the conversion of DC current of PV panels into AC to supply the load, with maximum efficiency and superior performance. The two stages of DC-DC-AC power conversion may result in usage of more circuit components, lower efficiency, higher cost and

${ }^{*}$ Corresponding author. 
larger size in comparison to the single stage one [1]. The modified diode assisted extended boost quasi-Z-source inverter has a single power conversion stage which perfectly suits for interfacing of renewable energy sources.

The efficiency and the voltage gain of the conventional q-ZSI are limited and comparable with the traditional system of a voltage source inverter with the auxiliary step-up DC/DC converter in the input stage [2] [3]. The concept of extending the quasi ZSI gain without increasing the number of active switches has been reported in the literature [4] [5]. These new converter topologies are known as extended boost q-ZSI and can be generally classified as capacitor assisted, diode assisted topologies and hybrid topologies [5] [6]. In this paper, MDAEB q-ZSI with continuous input current [7] is presented, analyzed and compared for the simple boost control technique. Simulation studies of the proposed inverter configuration are carried out in MATLAB/SIMULINK. The capacitor voltage in the impedance network, voltage gain, boost factor, voltage stress and THD are calculated and compared with the quasi z-source inverter. Hardware of the modified diode-assisted QZSI is developed and the simulation results are verified.

\section{Operating Modes and Steady State Analysis of MDAEB q-ZSI}

The proposed topology of MDAEB q-ZSI is presented in Figure 1. The topology of MDAEB q-ZSI could be derived by the adding of one capacitor (C3), one inductor (L3) and two diodes (D2 and D3) to the conventional q-ZSI. The connection points of the capacitor C3 is interchanged to reduce its operating voltages. Figure 2(a) and Figure 2(b) show the equivalent circuits of the MDAEB q-ZSI for the shoot-through and the active states.

The extended boost q-ZSI has two operational modes at the dc side, non-shoot-through states and the shootthrough state [8] [9]. During the shoot through state the q-ZSI performs the voltage boost function. During the active state, the previously stored magnetic energy in turn provides the voltage boost at the load terminals. The unique LC impedance network provides the boosting function without disturbing the operation inverter [10]-[12].

\subsection{Mode I (Shoot through Mode)}

Let $T=$ Operating period of the q-ZSI,

$T a=$ Active state,

$T s=$ Shoot through state,

$D a=$ The duty cycle of an active state,

$D s=$ The duty cycles of shoot-through state,

$$
\begin{aligned}
& T=T a+T s \\
& D a+D s=1 .
\end{aligned}
$$

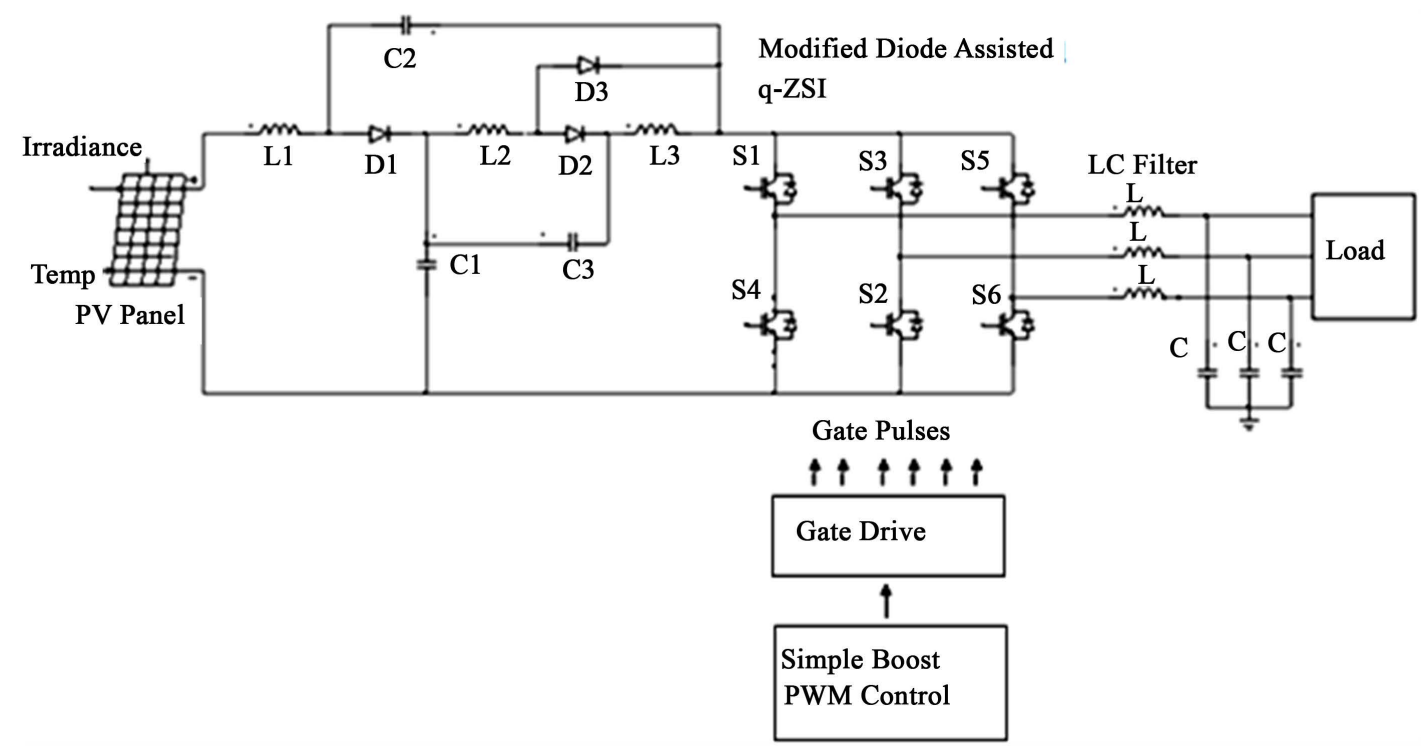

Figure 1. Modified diode assisted extended boost q-ZSI based PV system. 


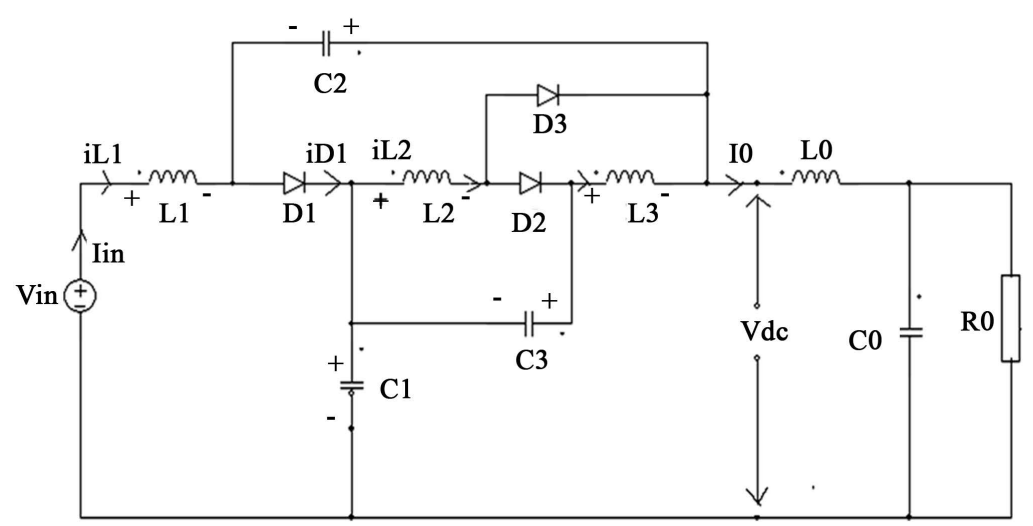

(a)

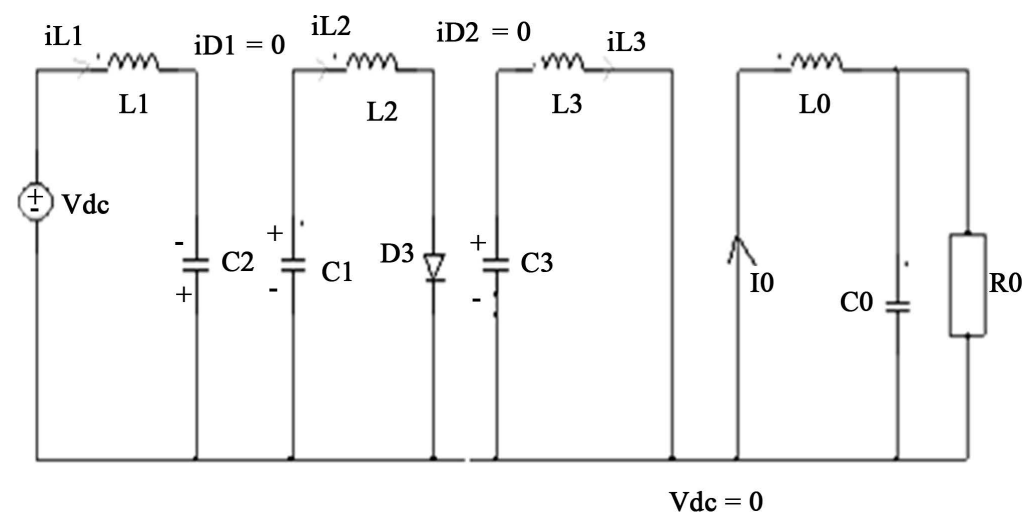

(b)

Figure 2. Operating modes of MDAEB q-ZSI: (a) Mode-I; (b) Mode-II.

The equivalent circuit of the MDAEB q-ZSI during the shoot-through state is shown in Figure 2(a). A unique LC impedance network is interfaced between the source and the inverter to achieve voltage boost and inversion in a single stage. During the shoot through state D3 is conducting and D1 and D2 diodes are in blocking state. All the inductors in the impedance network get charged up. Energy is transferred from the source to the inductor or the capacitor to the inductor when the capacitors are getting discharged.

The voltage across the inductors can be represented as

$$
\begin{gathered}
V_{L 1}=V_{i n}-V_{C 1} \\
V_{L 2}=V_{C 1} \\
V_{L 3}=V_{C 3}+V_{C 1} .
\end{gathered}
$$

\subsection{Mode II (Non-Shoot through Mode)}

The equivalent circuit of the MDAEB q-ZSI during the active state is shown in Figure 2(b). During the non shoot through state the diodes $D 1$ and $D 2$ are conducting and D3 is in blocking state. The inductors across the impedance network discharge and the capacitors get charged.

The voltage of the inductors can be represented as

$$
\begin{gathered}
V_{L 1}=V_{i n}-V_{C 1} \\
V_{L 2}=-V_{C 3} \\
V_{L 3}=-V_{C 3}-V_{C 2} .
\end{gathered}
$$

Peak DC-link Voltage is 


$$
V_{d c}=V_{C 1}+V_{C 2}=\frac{V_{i n}}{\left(D s^{2}-3 D s+1\right)} .
$$

The boost factor of the input voltage is

$$
B=\frac{V_{d c}}{V_{i n}}=\frac{1}{\left(D s^{2}-3 D s+1\right)} .
$$

\section{Simulation Results}

From the design considerations and specifications, the component parameters are calculated and it is presented in Table 1. MDAEB q-ZSI can be used for grid connected and standalone applications [13]-[16]. The simulation model of PV energy generation system with MDAEB q-ZSI for the boost factor $\mathrm{B}=2$ is shown in Figure 3 . This is constructed in the MATLAB/SIMULINK environment. Figure 4 shows the impedance network of MDAEB q-ZSI. The gating pattern of the pulse generation using the simple boost control technique is shown in Figure 5.

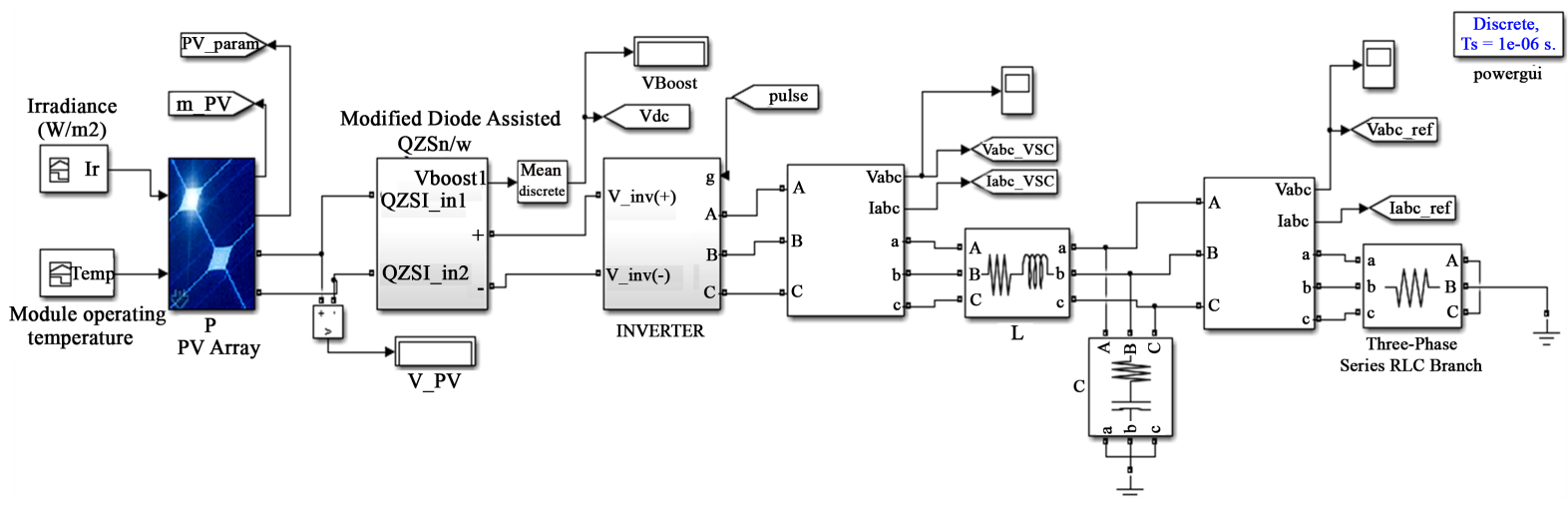

Figure 3. Matlab/Simulink circuit of PV based MDAEB q-ZSI.

Table 1. Simulation parameters.

\begin{tabular}{cc} 
Parameters & Values \\
\hline Input Voltage (PV Panle Vin) & $21 \mathrm{~V}$ \\
PV Panel Power & 100 Watts \\
Voc, Isc & $21.24 \mathrm{~V}, 4.7 \mathrm{~A}$ \\
Vmpp, Impp & $16.56 \mathrm{~V}, 4.3 \mathrm{~A}$ \\
Inductors L1, L2, L3 \& rL & $65 \mu \mathrm{H}, 0.005 \mu \mathrm{H}$ \\
Capacitors C1, C2, C3 \& rC & $185 \mu \mathrm{F}, 0.0005 \mu \mathrm{F}$ \\
Boost Factor (B) & 2 \\
Shoot through Duty Cycle Ds & 0.178 \\
Modulation Index (Ma) & 0.822 \\
Switching Frequency fs & $10 \mathrm{kHz}$ \\
Inverter Frequency & $50 \mathrm{~Hz}$ \\
R Load & $50 \Omega$
\end{tabular}




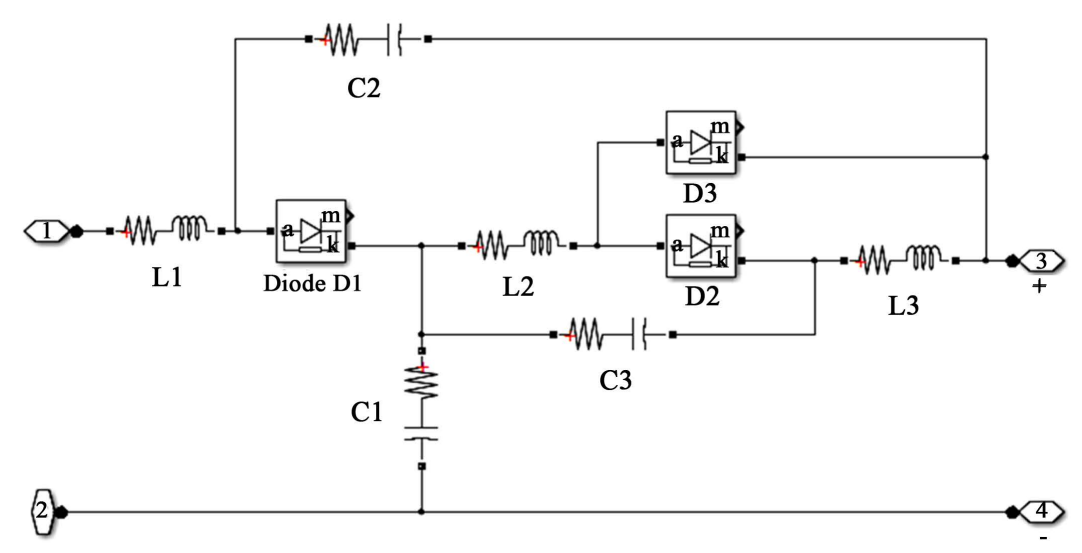

Figure 4. Impedance Network of MDAEB q-ZSI.

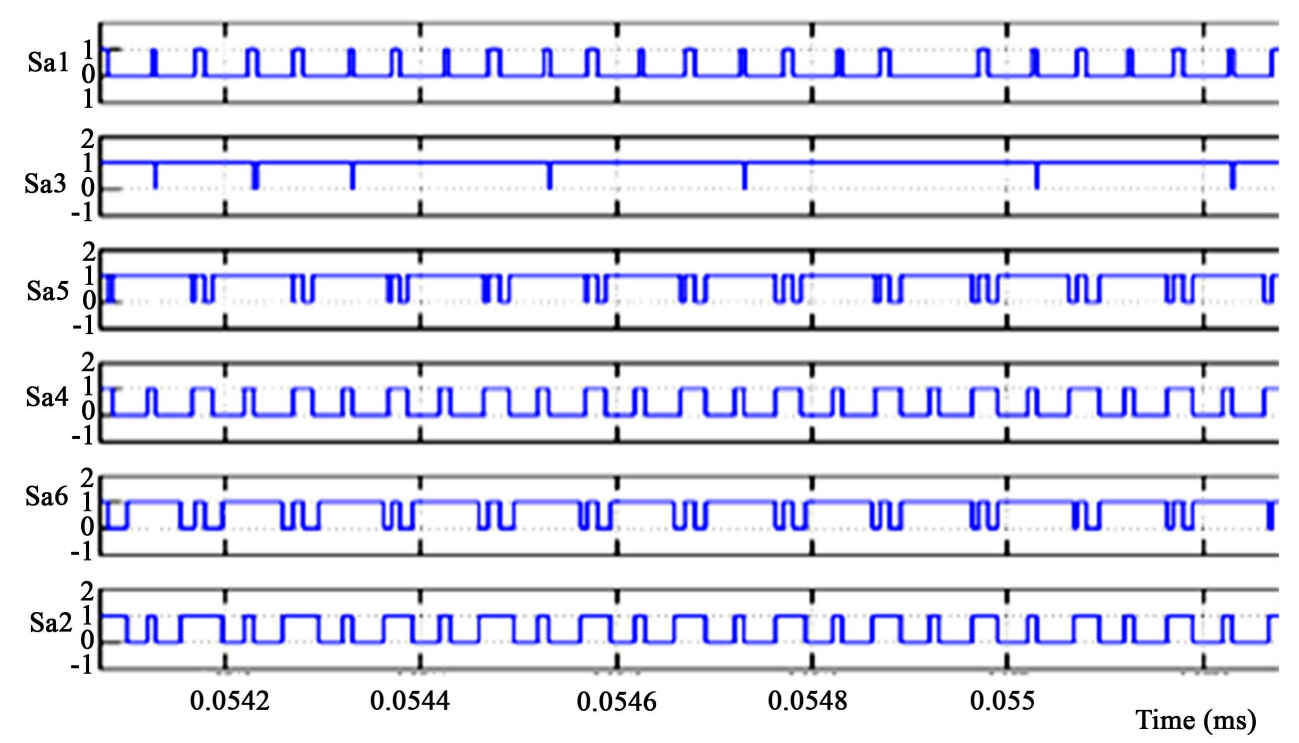

Figure 5. Shoot through pulses.

\subsection{PV Array Characteristics}

Figure 6 shows the PV array characteristics. The characteristics are plotted for different insolation level at constant temperature.

\subsection{Continuous Input Current}

The proposed topology has continuous input current as shown in Figure 7.

\subsection{DC-Link Voltage}

The proposed topology operates normally producing the demanded boost of the input voltage for the boost factor. The simulation results of DC link voltage of MDAEB q-ZSI is shown in Figure 8.

From Figure 8, it is clear that for the input voltage of $21 \mathrm{~V}$, MDAEB topology produce the boost voltage of $39 \mathrm{~V}$.

\subsection{Operating Voltages of the Capacitors in the Cascaded QZS Network}

The theoretical and simulated results of the capacitor voltages across the impedance network for the proposed topology are compared in Table 2. 

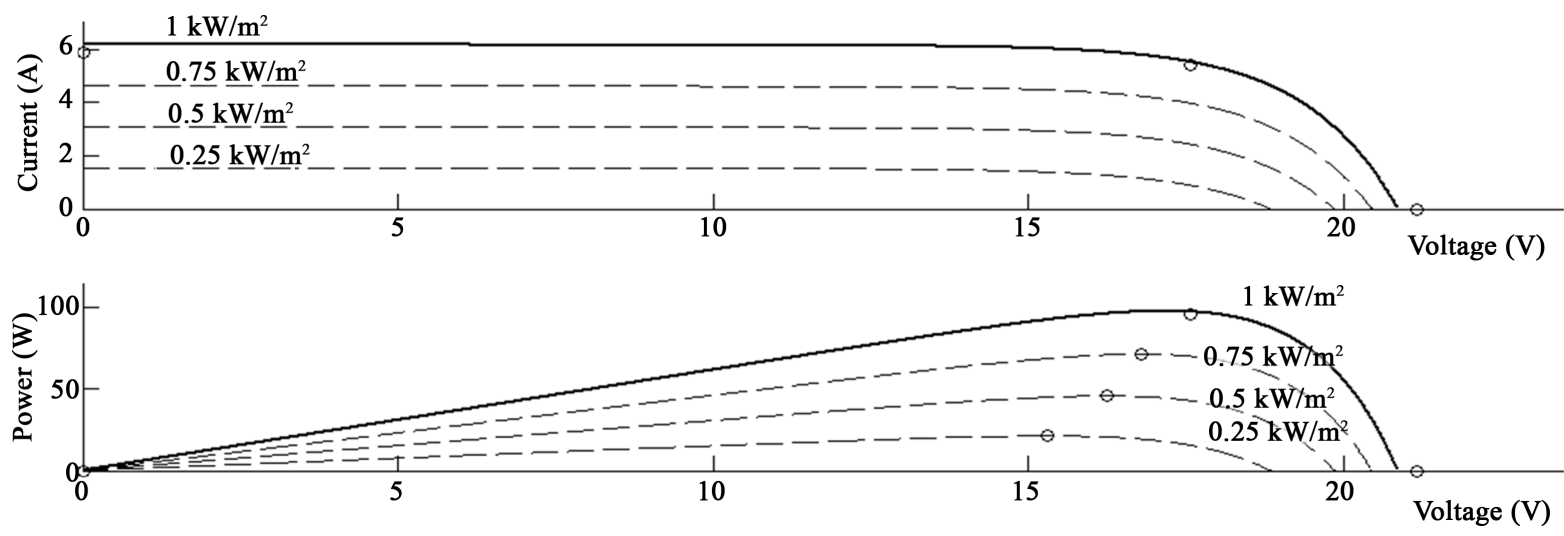

Figure 6. PV array characteristics.
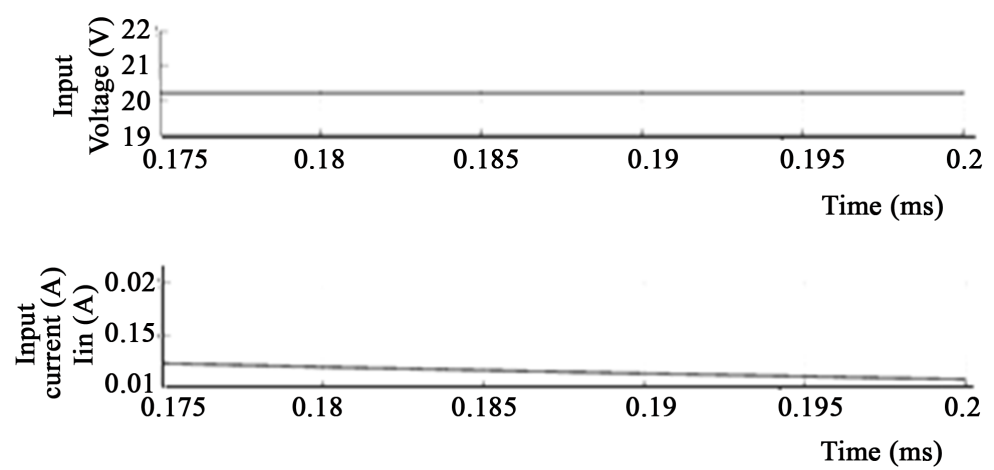

Figure 7. Input voltage \& current waveforms of MDAEB q-ZSI.

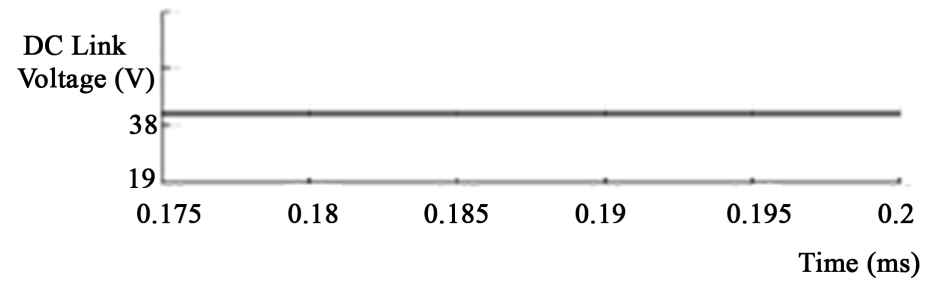

\section{Figure 8. DC Link voltage of MDAEB q-ZSI.}

Table 2. Operating voltages of capacitors in the impedance network.

\begin{tabular}{cccc}
\hline Capacitor Voltage $(\mathrm{V})$ & Formula & Theoretical Values (V) & Simulated Results (V) \\
\hline$V_{c 1}$ & $\frac{V_{\text {in }} *\left(D s^{2}-2 D s+1\right)}{\left(D s^{2}-3 D s+1\right)}$ & 28 & 26 \\
$V_{c 2}$ & $\frac{V_{\text {in }} *\left(2 D s-D s^{2}\right)}{\left(D s^{2}-3 D s+1\right)}$ & 6 & 5 \\
$V_{c 3}$ & $\frac{V_{\text {in }} *\left(D s-D s^{2}\right)}{\left(D s^{2}-3 D s+1\right)}$ & 6 & 5 \\
\hline
\end{tabular}

From Table 2 it is clear that the operating voltage of the capacitor C3 of MDAEB q-ZSI was reduced by more than five times by changing the interconnection points of the capacitors C3 as in Figure 1.

Figure 9 shows the operating voltages of the capacitors in the MDAEB q-ZSI. 


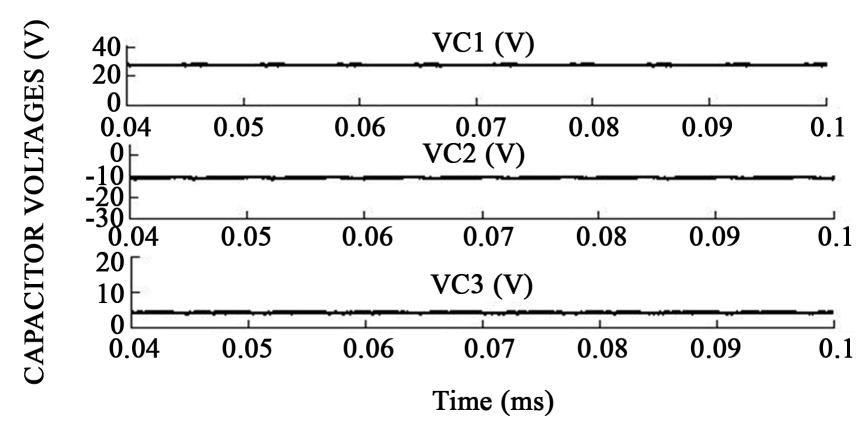

Figure 9. Capacitor voltages of MDAEB q-ZSI.

From Figure 9 the average voltage across the capacitor C3 of MDAEB q-ZSI was reduced more than six times when compared to its basic diode assisted topology. Figure 10 shows that the effect of modulation index on capacitor voltages of MDAEB q-ZSI.

From Figure 10 it is clear that the average value of voltage across the capacitor C3 of MDAEB q-ZSI was reduced with the increasing modulation index.

\subsection{Output Voltage and Current Waveforms}

The simulation results of the output line voltage, load voltage and load current waveforms of MDAEB q-ZSI for the simple boost modulation technique without filter are shown in Figures 11-13.

The simulation results of line voltage, load voltage and load current waveforms of MDAEB q-ZSI for Simple Boost technique with filter are shown in Figures 14-16. Filtered three phase output line voltage is shown in Figure 17.

\section{Performance Characteristics of MDAEB Q-ZSI}

Performance parameters of the MDAEB q-ZSI are analyzed for various modulation indices for the given boost factor. They are Total Harmonic Distortion, inductor current ripple of q-ZSI, capacitor voltage ripple, voltage gain and voltage stress, boost factor.

\subsection{Total Harmonic Distortion (THD)}

Total Harmonic Distortion of MDAEB q-ZSI is analyzed and compared with the conventional quasi ZSI for the simple boost modulation technique.THD is calculated for various modulation index values and the effect of the modulation indices on THD and the comparison is shown in Figure 18.

From Figure 18 THD increase with the decrease in the modulation index and the MDAEB q-ZSI has reduced THD, when compared to the quasi ZSI.

\subsection{Voltage Gain $(G)$}

Voltage Gain, $G$ is calculated for the simple boost modulation technique. In Figure 19 the voltage gain $G$ is compared with different values of modulation indices for the simple boost modulation technique.

Voltage gain, $G$ is given by,

$$
G=M * B
$$

where $M=$ Modulation Index,

$B=$ Boost Factor.

From Figure 19 it is clear that when compared with the conventional quasi ZSI, the proposed topology have increased voltage gain for the same value of the modulation index (Ma).

\subsection{Boost Factor $(B)$}

The boost factor is calculated for the simple boost modulation technique. In Figure 20, the boost factor $B$ is compared with different values of the shoot through duty cycle Ds. Boost factor is given by 


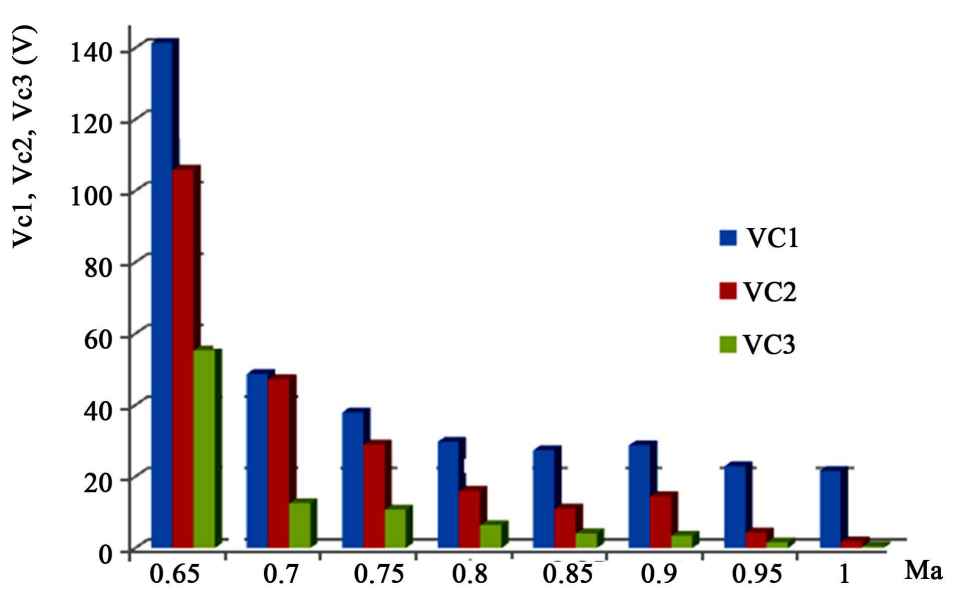

Figure 10. Effect of modulation index on capacitor voltage of MDAEB q-ZSI.

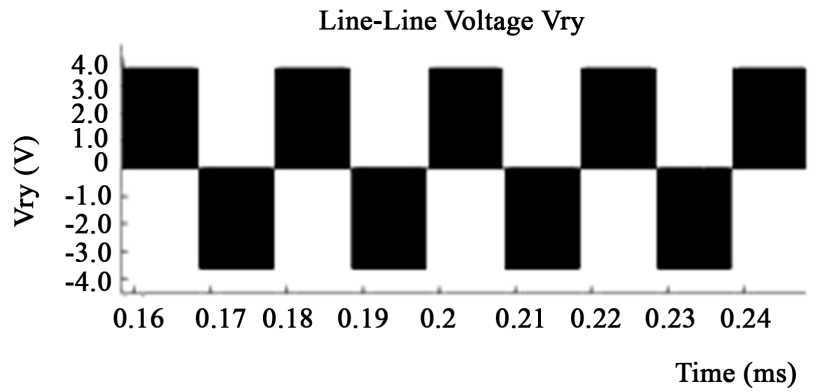

Figure 11. Line voltage waveform for MDAEB q-ZSI.

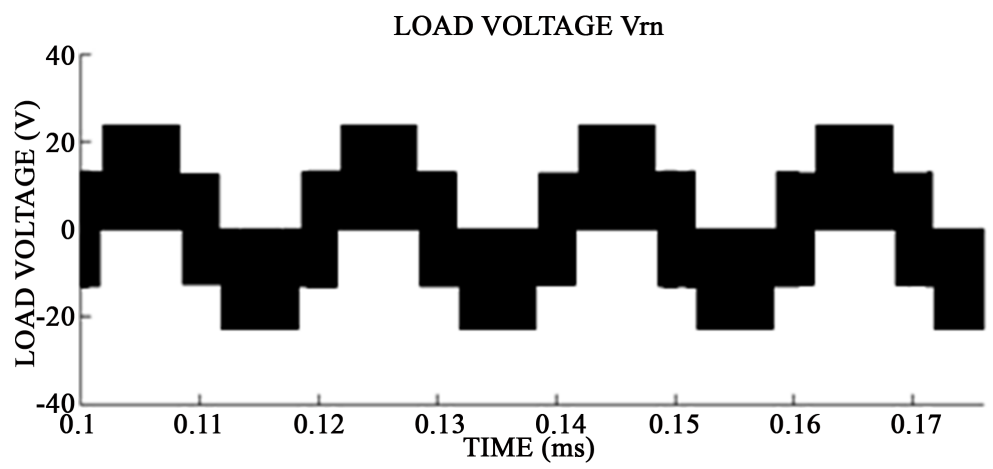

Figure 12. Load voltage waveform.

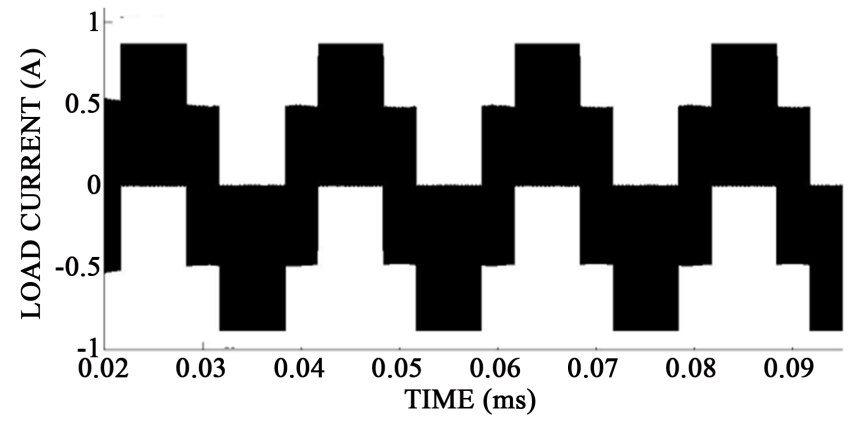

Figure 13. Load current waveform for MDAEB q-ZSI. 


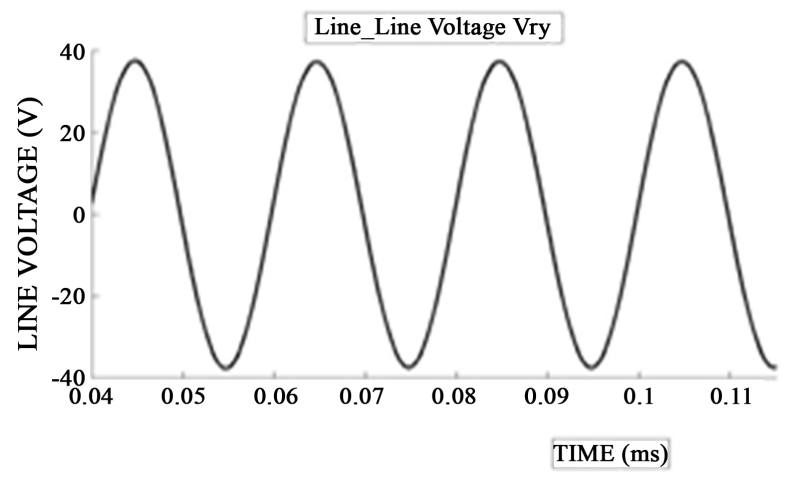

Figure 14. Filtered output line voltage waveform.

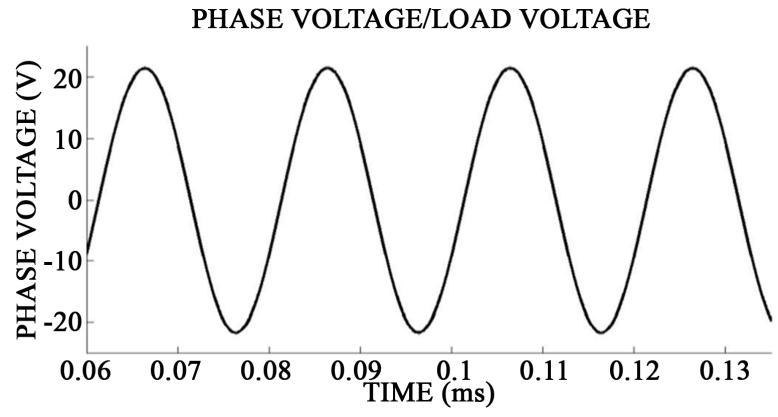

Figure 15. Filtered output load voltage waveform.

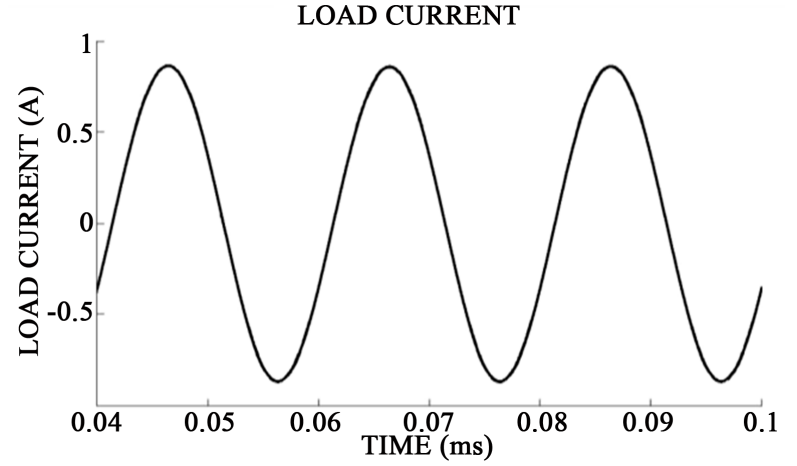

Figure 16. Filtered output load current waveform.

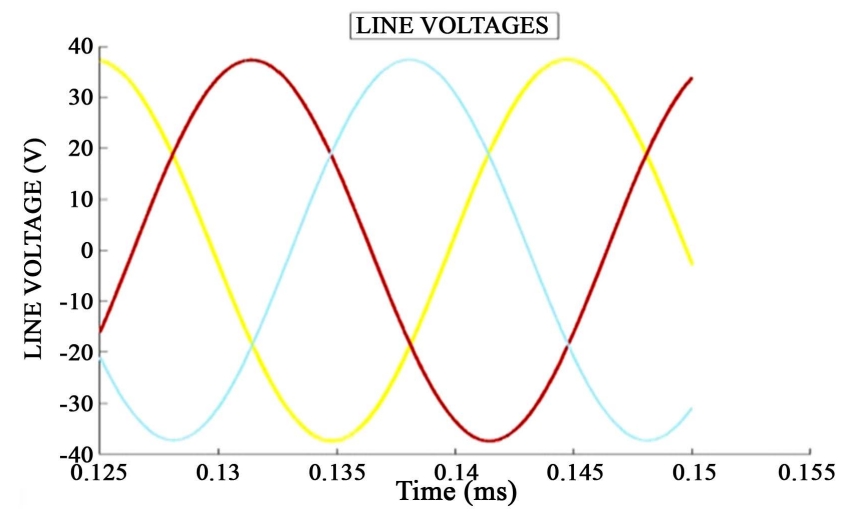

Figure 17. Filtered output line voltage waveform. 


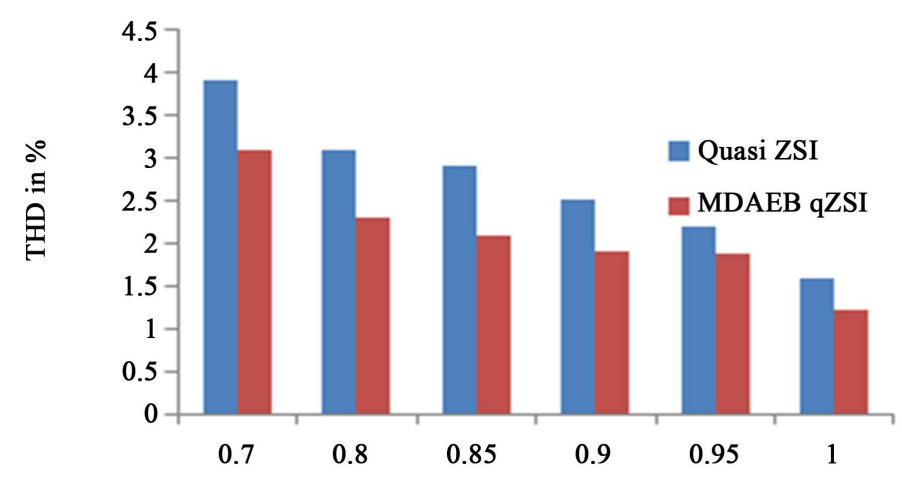

Figure 18. Effect of modulation index on THD.

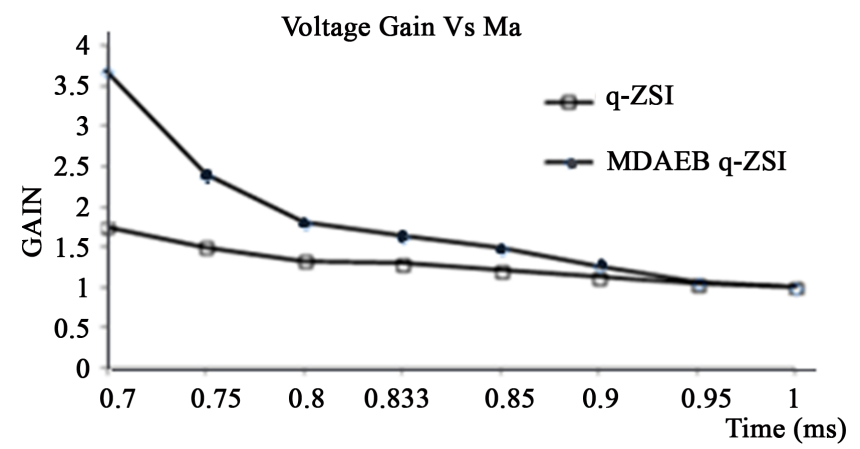

Figure 19. Comparison of voltage gain.

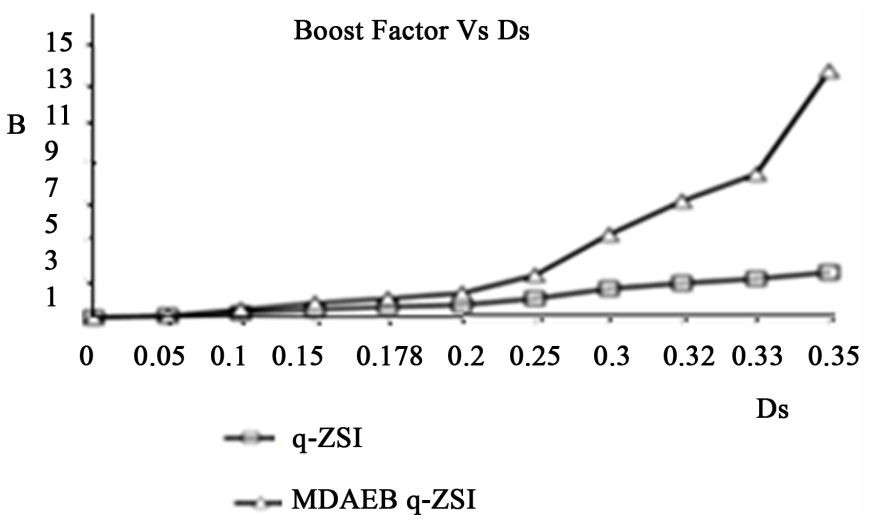

Figure 20. Boost factor comparison.

$$
B=\frac{1}{\left(D s^{2}-3 D s+1\right)}
$$

From Figure 20, the proposed topology have increased boost factor of the input voltage for the same value of the shoot through duty cycle Ds when compared with the conventional q-ZSI.

\subsection{Voltage Stress}

Voltage stress is compared with voltage gain for the simple boost modulation technique. Voltage stress is calculated from the voltage gain $G$. Figure 21 shows the variation of voltage stress/DC voltage with voltage gain $(G)$ for MDAEB q-ZSI and the traditional quasi ZSI.

Voltage stress across the devices is given by 


$$
V_{S}(2 * G-1) * V_{I N} \text {. }
$$

From Figure 21 it is clear that the simple boost PWM control technique gives better voltage gain and reduced voltage stress for the MDAEB q-ZSI than the conventional quasi ZSI.

From the simulation results it is observed that MDAEB q-ZSI gives higher RMS value of the output voltage, higher voltage gain, increased boost factor, reduced voltage stress and reduced THD when compared with the traditional quasi ZSI for the simple boost modulation technique. It provides reduced operating voltages of the capacitor C3. MDAEB q-ZSI is the preferred topology for the photovoltaic applications when compared to the conventional q-ZSI.

\section{Experimental Results}

In order to verify the theoretical assumptions the laboratory setup for MDAEB q-ZSI was assembled. The experimental setup for the PV connected MDAEB q-ZSI was shown in Figure 22.

The shoot through pulses and the gate pulses during the switching sequence of the three phase inverter are shown in Figure 23 and Figure 24. The shoot through duty cycle is 0.178 and the modulation index is 0.822 .

The boost voltage and the load voltage of the MDAEB q-ZSI are shown in Figure 25 and Figure 26. For the input voltage of $21 \mathrm{~V}$, the proposed topology produces the boost voltage of $42 \mathrm{~V}$ for the boost factor $\mathrm{B}=2$.

From the hardware results it is shown that modified diode assisted extended boost q-ZSI have continuous input current, high dc link voltage ,high demanded boost ,reduced voltage stress, increased voltage gain and increased load voltage.

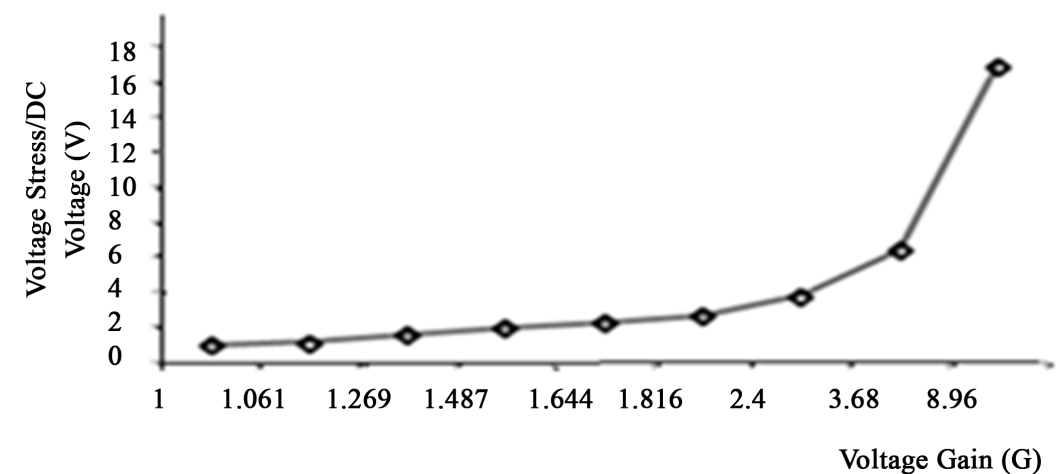

Figure 21. Effect of voltage gain on voltage stress.

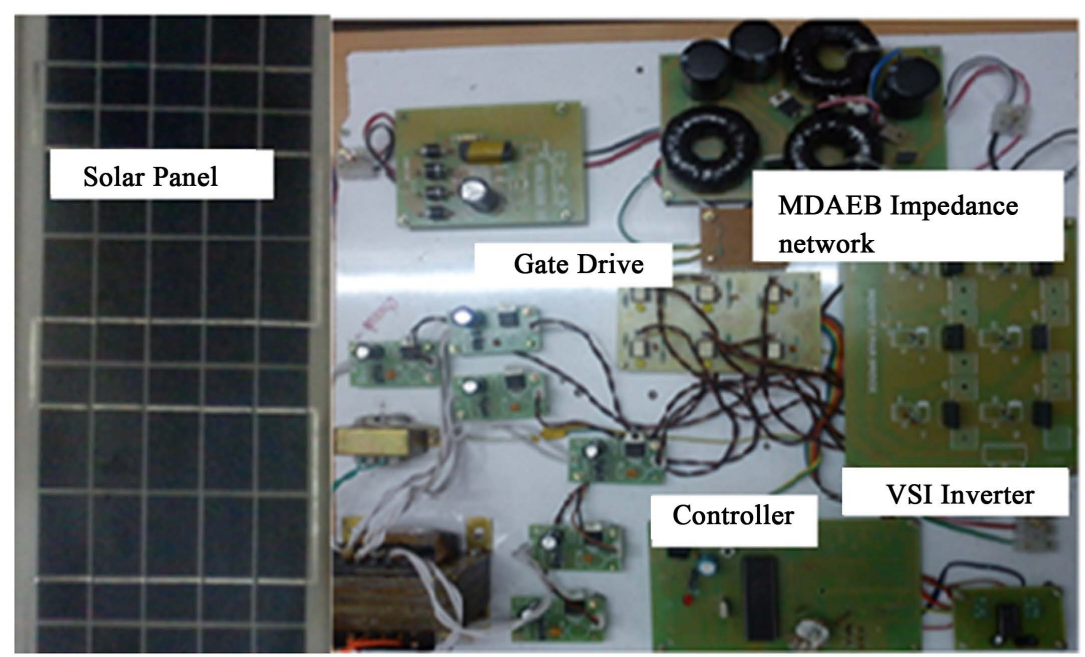

Figure 22. Experimental setup. 


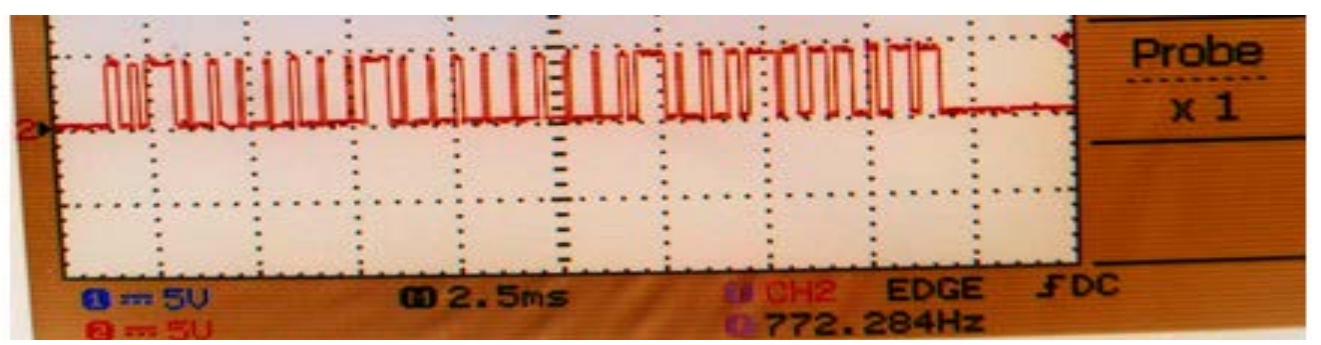

Figure 23. The shoot through pulses.

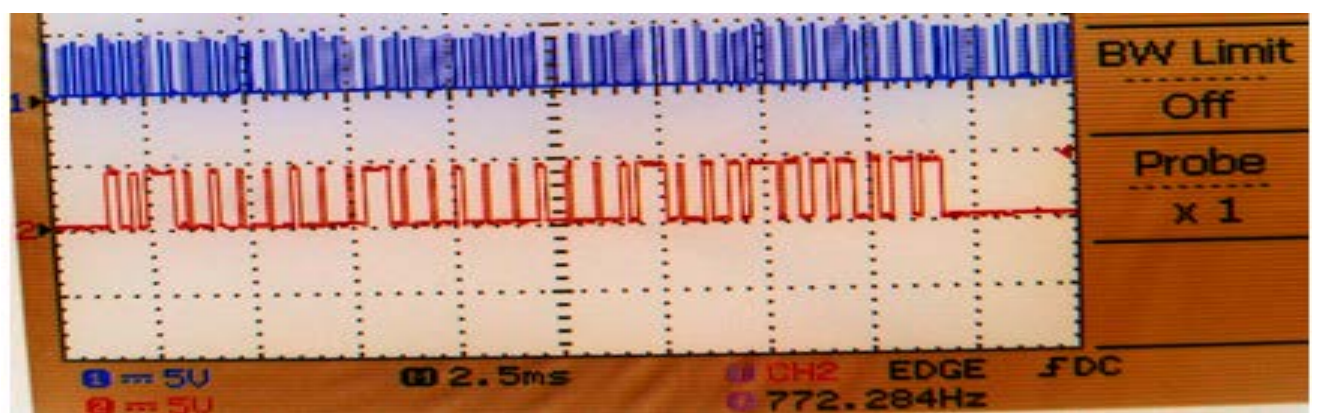

Figure 24. Gate pulses.

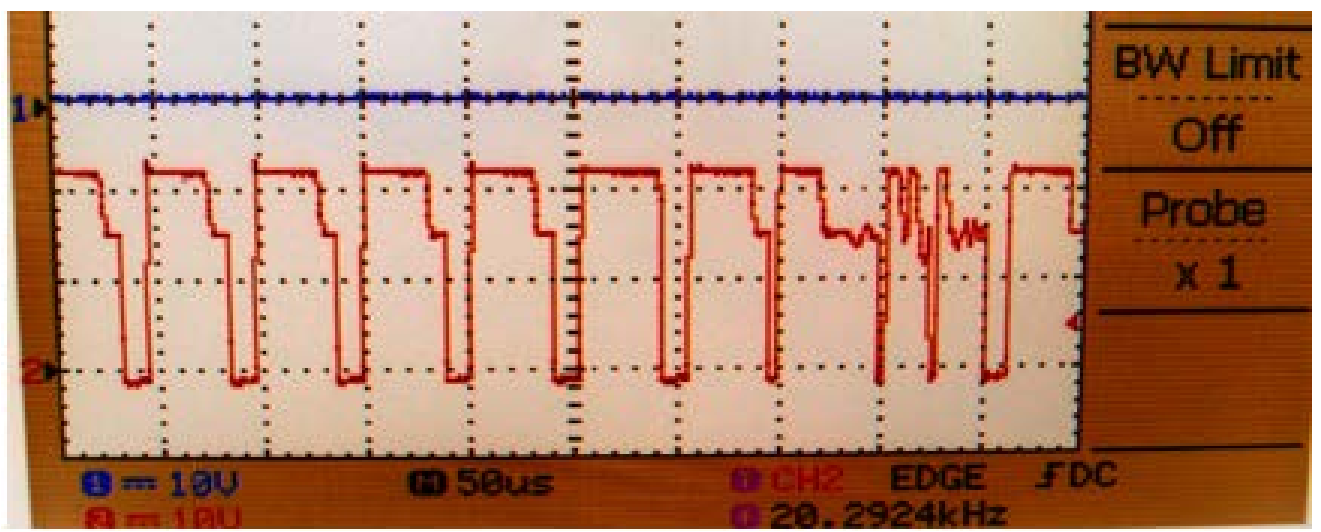

Figure 25. Boost voltage.

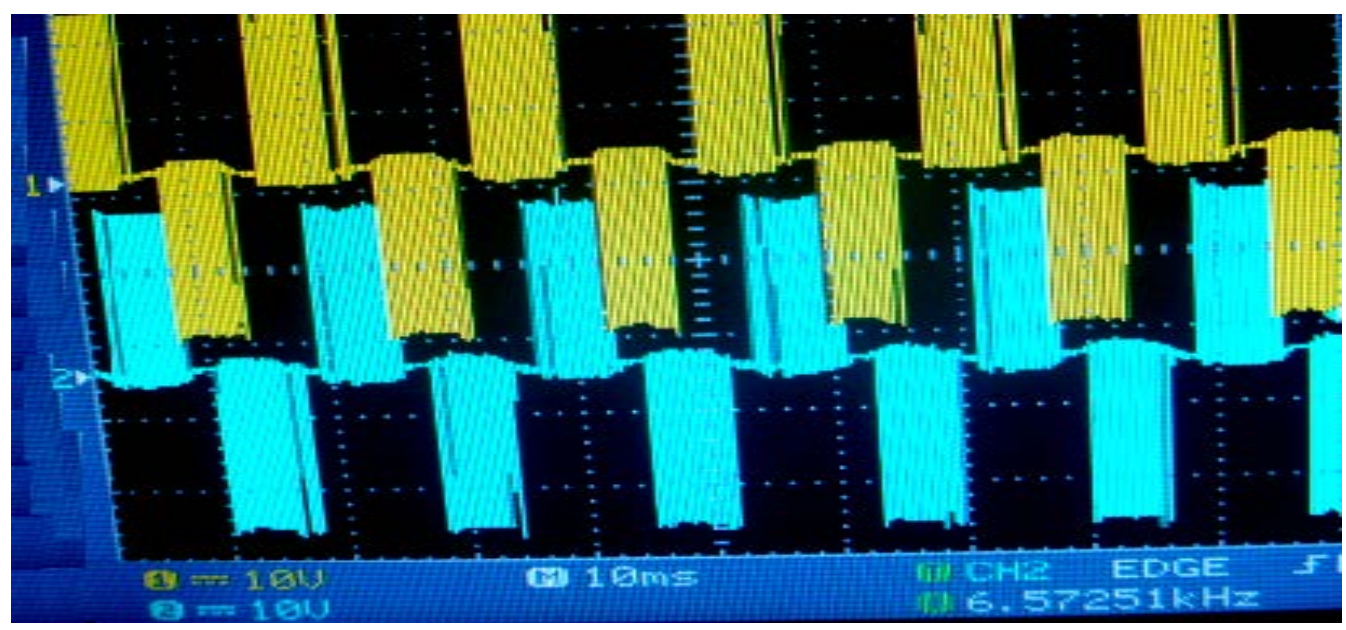

Figure 26. Output line-line voltage. 


\section{Conclusion}

In this paper, the topology of modified diode assisted extended boost quasi ZSI for PV applications has been discussed and compared with the conventional q-ZSI. The detailed steady state operation of the proposed topology is analyzed and simulated. Simulation results validate the theoretical analysis. From the results, it is observed that the voltage stress across the impedance network is reduced and the operating voltages of the capacitors are reduced by five times; reduced THD, higher boost factor and better spectral quality of the output are obtained compared to QZSI configuration. Therefore, the proposed topology of extended QZSI is suited for PV applications.

\section{Acknowledgements}

The authors wish to thank the management of SSN institutions for providing the computational facilities to carry out this work.

\section{References}

[1] Yang, L.-S., Liang, T.-J. and Chen, J.-F. (2009) Transformer Less DC-DC Converters with High Step-Up Voltage Gain. IEEE Transactions on Industrial Electronics, 56, 3144-3152. http://dx.doi.org/10.1109/TIE.2009.2022512

[2] Badin, R., Huang, Y., Peng, F.Z. and Kim, H.G. (2007) Grid Interconnected Z Source PV System. IEEE Power Electronics Specialists Conference (PESC’07), Orlando, 17-21 June 2007, 2328-2333. http://dx.doi.org/10.1109/pesc.2007.4342373

[3] Huang, Y., Shen, M.S., Peng, F.Z. and Wang, J. (2006) Z-Source Inverter for Residential Photovoltaic Systems. IEEE Transactions on Power Electronics, 21, 1776-1782. http://dx.doi.org/10.1109/TPEL.2006.882913

[4] Gajanayake, J., Luo, F.L., Gooi, H.B., So, P.L. and Siow, L.K. (2009) Extended Boost Z-Source Inverters. IEEE Energy Conversion Congress and Exposition (ECCE’09), San Jose, San Jose, CA, 20-24 September 2009, 3845-3852.

[5] Gajanayake, C.J., et al. (2010) Extended-Boost Z-Source Inverters. IEEE Transactions on Power Electronics, 25, 2642-2652. http://dx.doi.org/10.1109/TPEL.2010.2050908

[6] Vinnikov, D., Roasto, I., Strzelecki, R. and Adamowicz, M. (2010) Performance Improvement Method for the VoltageFed q-ZSI with Continuous Input Current. IEEE Mediterranean Electrotechnical. Conference (MELECON'10), Valletta, 26-28 April 2010, 1459-1464.

[7] Vinnikov, D., Roasto, I. and Jalakas, T. (2010) Comparative Study of Capacitor-Assisted Extended Boost qZSIs Operating in Continuous Conduction Mode. 12th Biennial Baltic Electronics Conference (BEC), Tallinn, 4-6 October 2010, 297-300.

[8] Li, Y., Jiang, S., Cintron-Rivera, J.G. and Peng, F.Z. (2013) Modeling and Control of Quasi-Z-Source Inverter for Distributed Generation Applications. IEEE Transactions on Industrial Electronics, 60, 1532-1541. http://dx.doi.org/10.1109/TIE.2012.2213551

[9] Peng, F.Z. (2003) Z-Source Inverter. IEEE Transactions on Industry Applications, 39, 504-510. http://dx.doi.org/10.1109/TIA.2003.808920

[10] Anderson, J. and Peng, F.Z. (2008) Four Quasi-Z-Source Inverters. IEEE Power Electronics Specialists Conference (PESC'08), Rhodes, 15-19 June 2008, 2743-2749. http://dx.doi.org/10.1109/pesc.2008.4592360

[11] Li, Y., Anderson, J., Peng, F.Z. and Liu, F.Z. (2009) Quasi-Z-Source Inverter for Photovoltaic Power Generation Systems. Applied Power Electronics Conference and Exposition (APEC 2009), Washington, 15-19 February 2009, 918924. http://dx.doi.org/10.1109/APEC.2009.4802772

[12] Cintron-Rivera, J.G., Li, Y., Jiang, S. and Peng, F.Z. (2011) Quasi-Z-Source Inverter with Energy Storage for Photovoltaic Power Generation Systems. Applied Power Electronics Conference and Exposition (APEC 2009), Washington, 15-19 February 2009, 401-406. http://dx.doi.org/10.1109/apec.2011.5744628

[13] Park, J.-H., Kim, H.-G., Nho, E.-C., Chun, T.-W. and Choi, J. (2009) Grid-Connected PV System Using a Quasi-ZSource Inverter. Applied Power Electronics Conference and Exposition (APEC 2009), Washington, 15-19 February 2009, 925-929. http://dx.doi.org/10.1109/APEC.2009.4802773

[14] Carrasco, J.M., Franquelo, L.G., Bialasiewicz, J.T., Galvan, E., PortilloGuisado, R.C., Prats, M.A.M., Leon, J.I. and Moreno-Alfonso, N. (2006) Power-Electronic Systems for the Grid Integration of Renewable Energy Sources. IEEE Transactions on Industrial Electronics, 53, 1002-1016. http://dx.doi.org/10.1109/TIE.2006.878356

[15] Liu, J.F., Jiang, S., Cao, D. and Peng, F.Z. (2013) A Digital Current Control of Quasi-Z-Source Inverter With Battery. IEEE Transactions on Industrial Informatics, 9, 928-937. http://dx.doi.org/10.1109/TII.2012.2222653 
[16] Zakis, J., Vinnikov, D., Roasto, I. and Ribickis, L. (2011) Quasi-Z-Source Inverter Based Bi-Directional DC/DC Converter: Analysis of Experimental Results. International Conference Workshop Compatibility and Power Electronices (CPE), Tallin, 1-3 June 2011, 394-399. http://dx.doi.org/10.1109/cpe.2011.5942267

Submit or recommend next manuscript to SCIRP and we will provide best service for you:

Accepting pre-submission inquiries through Email, Facebook, LinkedIn, Twitter, etc.

A wide selection of journals (inclusive of 9 subjects, more than 200 journals)

Providing 24-hour high-quality service

User-friendly online submission system

Fair and swift peer-review system

Efficient typesetting and proofreading procedure

Display of the result of downloads and visits, as well as the number of cited articles

Maximum dissemination of your research work

Submit your manuscript at: http://papersubmission.scirp.org/ 